\title{
Author Correction: GAPDH controls extracellular vesicle biogenesis and enhances the therapeutic potential of EV mediated siRNA delivery to the brain
}

Ghulam Hassan Dar, Cláudia C. Mendes, Wei-Li Kuan, Alfina A. Speciale (1D, Mariana Conceição, André Görgens (D), Inna Uliyakina, Miguel J. Lobo, Wooi F. Lim (BD, Samir EL Andaloussi (D), Imre Mäger (D), Thomas C. Roberts (D), Roger A. Barker, Deborah C. I. Goberdhan (1), Clive Wilson \& Matthew J. A. Wood (D)

Correction to: Nature Communications https://doi.org/10.1038/s41467-021-27056-3, published online 18 November 2021.

The original version of this Article contained an error in Fig. 1d. In Fig. 1d the labelling of the EVs and cell lysate in the bottom panel was inadvertently switched. This error has been corrected in the PDF and HTML versions of the Article.

Published online: 16 December 2021

(c) (i) Open Access This article is licensed under a Creative Commons Attribution 4.0 International License, which permits use, sharing, adaptation, distribution and reproduction in any medium or format, as long as you give appropriate credit to the original author(s) and the source, provide a link to the Creative Commons license, and indicate if changes were made. The images or other third party material in this article are included in the article's Creative Commons license, unless indicated otherwise in a credit line to the material. If material is not included in the article's Creative Commons license and your intended use is not permitted by statutory regulation or exceeds the permitted use, you will need to obtain permission directly from the copyright holder. To view a copy of this license, visit http://creativecommons.org/licenses/by/4.0/.

(C) The Author(s) 2021 